places in the cave, and they can always be found attached to excrementitious matter dropped by the bats, rats, and other animals which extend their range to the outer air. Fungi also grow on the dead bodies of the animals which die in the caves, and are found abundantly on fragments of wood and boards brought in by human agency. The rats also have brought into fissures and cavities communicating with the cave, seeds, nuts, and other vegetable matters, from time immemorial, which have furnished food for insects. Thus rats and bats have, no doubt, had much to do with the continuance of land life in the cave, and the mammals of the post-pliocene or earlier period, which first wandered and dwelt in its shades, were introducers of a permanent land life.

As to the small crustaceans, little food is necessary to support their small economy, but even that little might be thought to be wanting, as we observe the clearness and limpidity of the water in which they dwell. Nevertheless the fact that some cave waters communicate with outside streams is a sufficient indication of the presence of vegetable life and vegetable débris in variable quantities at different times. Minute fresh water algæe no doubt occur there, the spores being brought in by external communication, while remains of larger forms, as confervæ, \&c. would occur plentifully after floods. In the Wyandotte Cave no such connection is known to exist. Access by water is against the current of small streams which discharge from it. On this basis rests an animal life which is limited in extent, and must be subject to many vicissitudes. Yet a fuller examination will probably add to the number of species, and of these, no doubt, a greater or less number of parasites on those already known. The discovery of the little Lernæean shows that this strange form of life has resisted all the vicissitudes to which its host has been subjected. That it has outlived all the physiological struggles which a change of light and temperature must have produced, and that it still preys on the food of its host, as its ancestors did, there is no doubt. The blindness of the fish has favoured it in the "struggle for existence," and enabled it to maintain a position nearer the commissariat, with less danger to itself than did its forefathers.

E. D. COPE

\section{SCOTTISH COAL FIELDS}

THE "Journal of the Iron and Steel Institute" for August contains Prof. Geikie's paper read at the recent meeting in Glasgow " On the Geological Position and Features of the Coal and Ironstone-bearing Strata of the West of Scotland." The paper is meant chiefly for the benefit of those who are acquainted only with the British Carboniferous strata as seen in the English coal-fields, and to point out the geological position of the Scottish carboniferous deposits as contrasted with those of England. A geological map of Scotland shows that the Carboniferous formation is for the most part restricted to that broad belt of undulating low ground that extends from sea to sea, between the northern highlands on the one hand, and the southern uplands on the other. Throughout this area the strata are arranged in a series of great basins with intervening ridges. The chief basins, beginning in the east, the basins of Fifeshire, and Midlothian being first; second, the Lanarkshire and Stirlingshire basin; third, the broken and interrupted basins of Ayrshire and the south. This system is capable of being divided into four great series, which, beginning at the top, are as follows:-(1) the Coal Measures, (2) the Millstone Grit, (3) the Carboniferous Limestone (4) the Calciferous Sandstone series.

From Prof. Geikie's review of the more characteristic features assumed by the Scottish Carboniferous system, it is evident that the series which diverge most from those that are typical of the English area are the Calciferous Sandstones and the overlying Carboniferous Limẹstone series. In England, the strata that underlie the Coal Measures and Millstone Grit are composed almost exclusively of beds which have been amassed upon a sea bottom. In Scotland, on the other hand, we find the strata upon which the true Coal Measures and Millstone Grit repose giving evidence of numerous interchanges of land, fresh or brackish water, and marine conditions; while at the same time we are assured that during the accumulation of these underlying strata the eruption of melted matter hardly ever ceased in central Scotland.

\section{NOTES}

Those interested in the early history of geolozy will be glad to learn that a work is announced as ready for publication, with the title, "A Book about William Smith and the Somersetshire Coal Canal; being an Account of the Commencement of Stratigraphical Geology in England." The book is illustrated by a series of consecutive photographs of the districts along the north side of the Canal valley, and each photograph is accompanied by a geologically coloured key, which shows at a glance the outcrop of the various strata. This method is, as far as we know, quite original, and serves to show clearly the data with which Snith dealt in arriving at his discoveries.

THE Vice-Chancellor of the University of Cambridge, in resigning his office, referred to the progress made by the University in encouraging new branches of study. He commented upon the extension of the influence of the University over the studies in the kingdom, and the increasing desire on the part of those engaged in the work of education to be brought more closely in contact with the University. The yearly increase in the number of candidates for the Middle-class Examinations, and the institution of an examination for the higher grade schools, evidenced the fact of the extending influence of the University. The ViceChancellor referred to the munificence of the Chancellor, the Duke of Devonshire, in providing a school for Experimental Physics, and congratulated the University upon the approaching completion of the building of the Fitzwilliam Museum. The acquisition of the Leckenby collection of fossils to the Wood. wardian Museum was a worthy proof of the liberality of the Colleges and members of the University, as well as a graceful acknowledgement of the services of Prof. Sedgwick. The donations of Lord Walsingham and Miss Walcott were likewise valuable additions to the collections in the above-mentioned museum. Among other bequests and donations, the Vice-Chancellor particularly alluded to the bequests of Sir John Herschel and the Rev. R. E. Kerrich, and especially to the generosity of the Earl of Portsmouth in presenting the MSS. of Sir Isaac Newton.

THERE has been a marked increase during the present term in the University of Cambridge in the number of students who take advantage of the privilege of being allowed to reside out of their college. Since the scheme was established in 1869, eighty students have been admitted, a considerable number of whom devote themselves to the stud/ of natural science. The University payments for nine terms' residence, including the B.A. degree, do not greatly exceed $30 l$., and even with books and a tditional instruction the amount need not be much over 5ol. Th: number of freshmen entered at the University this year is 622 , as compared with 572 last year.

Dr. Brown-SEquARD, the eminent physiologist, has resigned the chair of Comparative and Experimental Pathology in the Faculty of Medicine in Paris, which he has occupied for several years. It is understood that this is preliminary to establishing his permanent residence in Boston, U.S.A.

AT a meeting of the Council of the Royal College of 